\title{
A Investigação Científica em Portugal
}

Com que pompa ouvi uma vez dizer, em provas de concurso, a um catedrático sabedor, que em Portugal não havia nem podia haver investigação científica! Dizendo isto, olhava-me de soslaio para notar uma impassibilidade que havia de contundir com o seu orgulho de desastrado pregoeiro anticientífico! Já ao tempo clínicas estrangeiras tinham adoptado a angiografia cerebral na prática corrente e davam a melhor atenção à leucotomia prefrontal, ambas, felizmente, inovações portuguesas.

E prosseguia em tom de censura, a que a sua situação e a gravidade com que proferia as suas palavras davam especial colorido. Como se numa terra onde se não sabe o que há feito nos outros países se pudesse fazer investigação!

Este catedrático proclamava o derrotismo científico e o seu brado tinha ressonância no meio escolar, onde possuía prestígio, fazendo lavrar a descrença duma incompetência colectiva, quando era apenas pessoal.

Este professor nunca conviveu com cientistas estrangeiros; raríssimas vezes atravessou a fronteira, mesmo em passeio turístico, contentando-se em ler e defender com entusiasmo doutrinas alheias. Era a negação do investigador, de isso tinha a consciência, e como o irritava essa inferioridade, negava a vantagem de se estimular entre nós a investigação.

Se cito este exemplo, a que outros, embora menos expansivos e agressivos, podia juntar, é porque há pessoas incapazes de fazer investigação, por desejarem desde logo chegar a resultados brilhantes, o que infeliz- mente nem sempre sucede, e não têm o menor entusiasmo em seguir determinado caminho experimental a fim de obter certo objectivo, embora modesto, mas sempre útil.

Depois, é mais fácil repetir o que dizem os livros e revistas, especialmente quando os outros têm dificuldade em consultar as origens. Vivem estes catedráticos unicamente de ciência alheia, esquecendo que ao professor universitário cabe outra missão a realizar.

O meio científico português está ainda muito apegado a um passado de que precisa afastar-se, procurando contribuir para o progresso da ciência, aspiração máxima dos centros universitários.

Pode dizer-se que a prática do ensino corrente não é compatível com a investigação científica. Não é exacto. Em Medicina, por exemplo, com o auxílio de assistentes devotados ao ensino e à investigação, um e outra se podem acumular com um pouco de boa vontade.

Há quem pretenda separar as duas funções, o que nem sempre é possível, especialmente em pequenos países como o nosso. Quando muito, poder-se-ia criar uma categoria de investigadores, separando do ensino os professores ou assistentes que tivessem dado provas inequívocas do seu valor no campo da investigação. Seria uma espécie de prémio aos que, em trabalhos anteriores, tivessem marcado a sua individualidade científica.

$\mathrm{O}$ que não se pode admitir é que professores com responsabilidade de ensino, reconhecendo a sua insuficiência para trabalhos de investigação, desencoragem os novos a tri- lhar essa orientação. As Universidades não podem nem devem ser constituídas por aqueles que apenas se contentam com a ciência feita. Perdem a sua característica máxima. Não há o direito de pretender diminuir o dinamismo que marca a situação destes centros de actividade investigadora em todo o mundo. Temos por obrigação enfileirar ao lado de aqueles que estimulam os que querem progredir e concorrer com o seu esforço para o bem comum.

Aos que, chegando ao professorado, julgam ter alcançado o máximo da carreira, devemos dizer-lhes que é necessário mais alguma coisa do que repetirem-se, anualmente, nas suas lições.

Por que não se exige aos professores, de tantos em tantos anos, a prova da sua actividade em trabalhos e publicações, podendo ser irradiados os que provarem a sua incapacidade em produção científica? Porquê deixar pulular essa categoria de mestres inactivos, espalhados pelas diversas Faculdades, e que não passam de ser o eco dos livros, sem contribuição de trabalhos próprios, nem referência à sua observação pessoal?

A época da dialéctica estéril passou. Hoje, o professor tem outras obrigações a cumprir, novas iniciativas a tomar, inéditas aspirações a propor aos seus colaboradores, esforçando-se por alcançar, na assiduidade dum trabalho bem condensado, novas aquisições.

Tem-se dito que a investigação científica só é útil quando são bons os resultados. E fala-se no elemento sorte, ou diz-se mesmo ser o melhor factor que auxilia os investigadores felizes. Talvez em alguns casos, possa favorecer os resultados. E digo 
talvez, pois ignoro o que seja a sorte nesta espécie de trabalho. Se não bafejou o investigador, é porque ele não soube condicionar convenientemente as experiências, porque lhe faltaram particularidades essenciais, porque não atendeu a todas as circunstâncias em que podia produzir-se um resultado compensador.

Basta teimar, voltar ao início, se há uma ideia ou programa a conduzir a série de experiências realizadas.

A persistência que depende da vontade, mais do que os arroubos de inteligência, consegue vencer dificuldades que, num dado momento, podem considerar-se insuperáveis. Já [Ramón y] Cajal lhe chamou a virtude dos modestos.

Quantos desalentos vêm perturbar os investigadores! Muitos tive; mas a minha vontade de triunfar acabou por os dominar. Lembremo-nos duma sentença, que julgo ser de Payot, e que é uma grande verdade: "Toda a obra notável que se consegue em arte ou ciência é o resultado de uma grande paixão ao serviço de uma grande ideia".

Esta frase leva-me para outro aspecto da investigação, a ideação do trabalho a elaborar. Não é só a experimentação que conduz ao sucesso; esta é, em geral, o meio de realizar uma obra, de obter uma certa finalidade.

Antes de tentar um determinado trabalho científico é necessário que a elaboração mental indique o caminho a seguir, e se estudem os meios para alcançar o desejado objectivo, tomando em consideração todas as etapas a realizar, apreciando os diversos contratempos que possam aparecer e a forma como devem ser resolvidos.

Sem meditação, todo o esforço será inútil. As experiên- cias só terão sucesso quando assentem em base sólida e sejam conduzidas com ânimo vivo, para fazer realçar todos os resultados úteis no trilho que as há-de levar a bom termo.

É necessário, além disso, que o investigador tenha, como diz Cajal, "fé robusta em si mesmo, sem a qual nenhuma investigação alcança termo feliz".

Por outro lado, o investigador não pode dispersar-se, tem de viver dia e noite o seu objectivo, deixar-se dominar por completo pela sua ideia que, ininterruptamente, vai tomando modalidades diferentes no constante labutar do pensamento, apresentando ora perspectivas felizes ora dificuldades tremendas, que é necessário vencer na luta iniciada.

in Confidências de um investigador cientifico, Lisboa (1949)

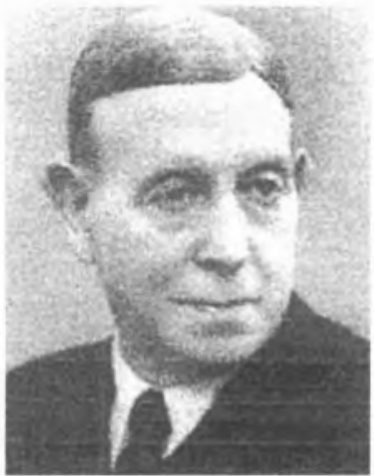

Egas Moniz (1874-1955)
António Caetano de Abreu Freire Egas Moniz nasceu em Avanca, em 29 de Novembro de 1874. Foi educado pelo seu tio. abade de Caetano Sá Freire, até se inscrever no curso de Medicina da Universidade de Coimbra. Especializou-se em Bordéus e Paris, tendose tornado professor da Universidade de Coimbra em 1902. Em 1911 ocupou a recém-criada cátedra de Neurologia da Universidade de Lisboa, lugar que manteve até à sua morte.

Entrou na política em 1903. tendo sido deputado até 1917, ano em que foi nomeado Embaixador de Portugal em Espanha. Nesse mesmo ano foi nomeado Ministro dos Negócios Estrangeiros. Presidiu à delegação portuguesa na Conferência de Paz de Paris de 1918.

Descobriu a angiografia cerebral e a leucotomia pré-frontal. Pelo valor terapêutico desta última técnica no tratamento de algumas psicoses, recebeu o Prémio Nobel de Fisiologia ou Medicina de 1949 (partilhado com o suiço Walter Rudolf Hess), único até hoje concedido a portugueses. Entre as suas obras mais importantes contam-se as seguintes: $A$ vida sexual (fisiologia e patologia), 1901; A neurologia na Guerra, 1917; Um ano de política. 1920; Júlio Dinis e a sua obra, 1924; O padre Faria na história do hipnotismo, 1925; L'angiographie cérébrale. ses applications et résultats en anatomie, physiologie et clinique, 1934; La leucotomie préfrontale. Traitement chirurgical de certaines psychoses, 1937; Clinica dell angiografia cerebrale. 1938; Die cerebrale Arteriographie und Phlebographie, 1940; Ao lado da Medicina, 1940; Trombosis y otras obstrucciones de las carótidas, 1941; História das cartas de jogar, 1942; Conferências médicas, 1945-1947; Die präfrontale Leukotomie, 1949; Confidências de um investigador científico, 1949. 